\title{
SPECIAL ECONOMIC ZONES (SEZs) ALONG THE KOREAN DEMILITARISED ZONE: A FEASIBLE PATHWAY TOWARDS AN ACCESSIBLE NORTH KOREA? ${ }^{12}$
}

\author{
BERNHARD KÖPPEN \\ University of Koblenz-Landau, Institute of Natural Science, Geography Division, Landau, Germany
}

Manuscript received July 13, 2010

Revised version November 29, 2010

KöPpen B., Special Economic Zones (SEZs) along the Korean Demilitarised Zone: A feasible pathway towards an accessible North Korea? Quaestiones Geographicae 29/4, Bogucki Wydawnictwo Naukowe, Poznań 2010, pp. 95-109, 2 figs, 3 tables. DOI 10.2478/v10117-010-0035-0, ISBN 978-83-62662-30-2, ISSN 0137-477X.

AвSTRACT: The Demilitarised Zone (DMZ) between the Republic of Korea (RoK) and the Democratic People's Republic of Korea (DPRK) is judged to be the last border of the Cold War. Although no peace treaty has been signed after the Korean War, astounding changes in the South-North relations could be observed between the late 1990s and 2010. Although severe provocations of the North finally led to a new stop of a further rapprochement, the unexpected reconciliation process started in 2000 by South Korea not only led to a temporary detente, but also showed spatially manifested results. Two Special Economic Zones, one dedicated to tourism and the other to industrial production, had been established in the DPRK near the DMZ. What is the appropriate interpretation of those diffident cross-border activities which lasted for almost a decade? Were these SEZs really first successful attempts at feasible Korean cross-border cooperation? Summing up all knowledge on North-Korean SEZ policy and the general state doctrine, it seems that real cross-border cooperation could not be an option for the DPRK's current leadership, either before or after South-Korea's adoption of Sunshine Policy.

KeY words: Korean Demilitarised Zone, Republic of Korea, Democratic People's Republic of Korea, cross-border cooperation, Special Economic Zones

Bernhard Köppen, Institut für Naturwissenschaften und Naturwissenschaftliche Bildung, Universität Koblenz-Landau, Campus Landau, Fortstraße 7, D-76829 Landau, Germany; e-mail: koeppen@uni-landau.de1.

1 The author is aware that thinking and writing about the DPRK is inevitably subject to rough interpretation and even speculative arguments, as empirical research in North Korea cannot be carried out according to scientific standards. Also rapid changes in the Korean border question might occur at any time. What is 'true' today can be turned over by an unexpected change tomorrow. Thus, this paper is to be regarded as a proposition of how to assess North-South cross-border cooperation on the Korean peninsula as interpreted by the situation in the summer of 2010.

2 This research partially benefited from a grant of the Asia Research Fund as part of the joint research project of the Hanns-Seidel-Foundation (Seoul Office), the TU Chemnitz (Sozial- und Wirtschaftsgeographie) and the Universität Koblenz-Landau (Juniorprofessur Demographieforschung) on "Sustainable development, economic growth and environmental protection in border regions in Northeast Asia - a comparison of the Korean and the German case". 


\section{Introduction}

Political borders are relative constructs. This finding is neither new nor astounding. As recent history has shown in Europe, tangible political borders can change - even vanish - within a short period of time (however, invisible borders in minds remain much more persistent as they are results of long historical processes and social practice).

Given those observations and taking into consideration the political, economic and societal changes in a globalised, market-economy-dominated world, it seems that borders and nationstates are becoming less important. Certain authors, such as Kenichi Omahe, even tend to argue that the concept of nations is being replaced by smaller, economically defined areas of worldwide importance (Omahe 1995).

If this point of view is taken as a basis, the Korean experience with its most severe, hypercontrolled border separating the North from the South must seem not only striking, but even bizarre. Together with the equally inhuman border in Gaza, the inner Korean border occurs as a dinosaur amongst political boundaries worldwide.

However, the Korean example of an extremely closed border is not the only proof that boundaries of nation-states are still powerful constructs (see also the Mexico-U.S. border, or the mechanisms of the Schengen Area to control its outer border).

The Demilitarised Zone (DMZ) between the Republic of Korea (RoK) and the Democratic People's Republic of Korea (DPRK) is regarded as the last remaining border of the Cold War (e.g. Kim 2001). In spite of this, there have been enormous changes in the North-South Korean relations since the year 2000 until the spring of 2010, when conditions changed totally again after a North Korean submarine obviously attacked and sunk the Cheonan, a South Korean battleship, in the South Korean waters.

Regarding Korean cross-border issues since the mid-1990s, there were several changes. First of all, diplomatic contact was established, generally enabled through a major change in South Korean politics called Sunshine Policy. Later, the DPRK opened up a little bit and allowed certain activities of international aid, NGOs as well as private investors. In this context, the planning and establishment of two North Korean Special Economic Zones (SEZ), both situated almost "at" the border, by using massive South Korean investment was amongst the most striking activities. The first SEZ, Geumgangsan (Diamond Mountains), was dedicated to tourism, whilst the Gaesong Industrial Complex was designed for maquila-type contract processing. Some hope was put into the idea that these very first attempts at cross-border cooperation might be the germ for the opening up of the DPRK in the future; if not even towards Korean unity.

Due to continuous provocations from the DPRK towards the Republic of Korea, all rapprochement activities have stopped by 2010 . The range of problematic issues shifted from internationally noted nuclear issues to less known incidents, such as the mysterious killing of a South Korean tourist in Geumgangsan in 2008.

On the other hand, it is a fact that the DPRK and the Republic of Korea have just had almost one decade of tangible cross-border interaction, with Kim Dae-Jung's visit to Pyong-Yang in 2000 as an official starting point and the official end in 2010 due to the Cheonan incident.

This leads to the question of how the spatially manifested cross-border activities could be assessed in an appropriate manner. Were both SEZs of Geumgangsan and Gaesong - despite the current tensions - successful attempts at feasible Korean cross-border cooperation, and might those projects still carry a germ for Korean reconciliation? Putting into question the North-Korean point of view: How does cross-border cooperation get along with a state doctrine based on selfchosen isolation and a farthest possible autarky? Was the idea of establishing cross-border cooperation ever a real option? Or must the above-mentioned rapprochement be judged as an unwilling but inevitable and finally temporary occurrence, due to the squalid economic situation of North Korea?

The findings in this paper are based on intensive literature and newspaper analysis, on expert interviews in South Korea, and a stay in the Geumgangsan Special Tourist Zone in 2006. 


\section{From confrontation to first cross- border cooperation and back}

Using Martinez' (1994) classification of crossborder relations, the Korean case is what could be called an "alienated borderland". Each side shows a hostile, even aggressive, attitude towards the other. Cross-border interactions do not take place or are limited to a minimum. Although a similar situation was in Central Europe with its Iron Curtain from the early 1960s until 1989, in real life cross-border relations - particularly with regard to economic activities - had been rather intense.

So it was quite surprising when the South Korean Sunshine Policy of peace and mutual understanding was officially established in 2000 . The Republic of Korea became an important partner of human-aid, trade and commercial investments to the DPRK for almost one decade.

In political terms, Sunshine Policy is based on peaceful cooperation and seeks reconciliation, with a potential for Korean reunification. It is founded on three principles:

- zero tolerance for aggression and provocations from the North,

- no intention of unification through absorption of the North by the South,

- taking measures to enhance reconciliation and mutual exchange by the South, including the separation of political cooperation from economic cooperation.

The South Korean government held the view that Kim Jong-Il's regime was not going to collapse in the near future (despite its severe economic problems, and not even after the leader's decease).

Keeping in mind that the U.S. has currently about 28,000-strong troops in South Korea and the Republic of Korea's military counts another 655,000 men (and of late also some women) facing an estimated 1.1 million or more in the North, aggression cannot be a future-oriented strategy, indeed. Another argument stresses historical experience. In view of the failed U.S. policy concerning the regimes in Cuba, Libya, Afghanistan or Iraq, aggressive approaches do not seem to be very efficient anyway.

Against this background, it was argued that bilateral tensions could only be reduced by a pol- icy of mutual reconciliation, trust and normalisation of political and economic relations. Sunshine Policy has been strongly influenced by the experiences of the German unification. On the one hand, Brandt's Ostpolitik of a peaceful rapprochement serves as an example that a similar process could soothe the tension and eventually lead towards Korean unity. On the other hand, regarding the enormous efforts of the German unification, it was concluded that absorption of the North cannot be a feasible strategy anyway. The expected costs and further ramifications of a reunification after a DPRK breakdown would be far beyond the ability of South Korea's economy to handle. Instead, a strategy of preventing such a situation by stabilising the North "beforehand" has been developed. Thus, the Republic of Korea engaged in humanitarian aid and loosened its restrictions on the private sector's investment in North Korea. One should not forget that before Sunshine Policy started, cross-border interaction was illegal and unwanted in both Korean states. The improvement of bilateral relations should encourage political and economic reforms with a successive opening up of the border. In the very end, the major goal was a so-called "soft-landing" of the North society and economy, without the urgent need of external aid to enable the survival of the North Korean people. But - so ran the idea - if North Korea's economy might improve, this might also induce political reforms and change. Then, maybe further thoughts on Korean unity or a Korean confederation could be appropriate.

The Sunshine Policy idea was first articulated in 1998 and implemented by former South Korean president Kim Dae-Jung, who was also awarded the Nobel Peace Prize in 2000 for this new leitmotiv.

In this respect, one important detail should not be forgotten. The basic impulse for Sunshine Policy is strongly related to the founder and leader of the Korean industrial conglomerate (chaebol) Hyundai, Chung Ju-Yung. Chung was born in today's North Korea. As a Korean patriot, the idea of reunification was one of his basic beliefs for lifetime. Hence, on learning about North Korea's most shocking famine in the mid-1990s, he was looking for contact with the DPRK leaders (bypassing official diplomatic restrictions) in order to offer assistance and help. Chung was finally al- 
lowed to send 500 head of cattle over the Demilitarised Zone as a symbol of reconciliation and compassion as well as real relief to the starving North. Immediately Chung Ju-Yung held - successful - informal negotiations on cross-border issues, such as the establishment of a Geumgangsan (Diamond Mountains) special tourist zone to attract South Koreans on a day-trip basis.

Later it was revealed that the whole process, from the first unofficial contact to the formal meeting of the presidents in Pyong Yang in 2000, was accompanied by the payment of enormous bungs in hard currency to the DPRK's notoriously broke regime. Nevertheless, Chung's individual commitment was probably the elementary condition for the Sunshine Policy proclaimed later by the South Korean government.

Despite the very "physical" closed border, the implementation of a SEZ in the DPRK with South Korean partners could almost serve as an argument for Kenichi Omahe's expected "end of the nation-state". "Put simply, in terms of real flows of economic activity, nation-states have already lost their role as meaningful units of participation in the global economy of today's borderless world" (Omahe 1995: 11). Not the government, but business was able to put down the barrier in Korea, at least to a certain extent. The "nationstates" themselves proved to be incapable of such an achievement. But this kind of explanation is certainly somewhat bold, as Chung was not only following capitalist interests but also driven by very individual feelings and patriotism.

After at least some constructive dialogue had been established, a kind of reunification euphoria came up in the South, which was squared by the DPRK's kind of friendly attitude. In the media and official statements, critical opinions about the Northern regime and its supposed atrocities towards people almost vanished.

The first significant tension occurred when the U.S. labelled North Korea as part of the "Axis of Evil“. Talks with the South were temporarily suspended. In 2002 military aggression over a disputed fishing territory chilled down the relations even more. Four South Korean sailors were killed.

However, South Korea's president Roh MooHyun continued the policy of his predecessor Kim Dae-Jung in principle. The relations on the divided peninsula became a little better again. In 2003, when the possession of nuclear weapons by the North became an issue and its further semiand illegal activities were revealed (such as the counterfeiting of American money or not settling international invoices), the Korean dialogue suffered another setback.

Earlier that year the South Korean policy towards North Korea had to be reconsidered as details of the so called cash-for-summit scandal were uncovered. As it turned out, a secret payment of millions of dollars by the Kim Dae-Jung administration to the DPRK ensured the organisation of the famous summit in 2000 where Kim Dae-Jung and Kim Jong-Il met (Kirk 2003). This money transfer was managed by the private company Hyundai Asan, holding the monopoly for developing and managing the Geumgangsan Special Tourist Zone and the Gaesong Special Economic Industrial Zone. As a consequence of the scandal, Chung Mong-Hun, the Chairman of Hyundai Asan and son of the Hyundai founder Chung Ju-Yung, committed suicide.

Nevertheless, the Republic of Korea continued its humanitarian aid for the North and maintained close cooperation concerning the Geumgangsan Special Tourist Area and the Gaesong Industrial Park.

South Korea stayed with a policy of de-escalation and reconciliation despite the notoriously unpredictable and somewhat intractable behaviour of the DPRK regime concerning international affairs as well as the Korean dialogue. However, the leitmotiv was slightly changed from the optimistic Sunshine Policy towards a much more cautious motto called "a policy of peace and prosperity".

The internationally noted and potentially threatening nuclear and missile tests of the DPRK army finally led to a stop of South Korean aid in October 2006. This turnaround was regarded as most overdue by sceptics of any form of Sunshine Policy. The "friendly approach" was mainly criticised for helping the notoriously hostile and threatening Northern regime to survive even longer instead of promoting reforms and mutual understanding.

It became even more obvious that all North Korean agreements did not involve a real shift in politics, but were directly connected to the deso- 
late state of the DPRK economy, which forced the regime to welcome any source of currency which could guarantee its survival. Furthermore, some critics feared that Sunshine Policy could weaken the relations between the U.S.A. and the Republic of Korea. It was argued that concerns of the North must not be favoured and put over the interests of the United States, as this ally is of vital importance for South Korea.

Discussion followed about what the future policy towards the DPRK should be, as provocations seemed to be a persistent issue, whatever friendly measures originated from the South. Thus, in 2008 the newly elected president Lee Myung-Bak announced a toughening of the RoK's stance towards the DPRK and stopped foodstuff supply as long as North Korea followed a nuclear programme. Reactions from Pyong Yang were rather fierce although Lee sought closer economic cooperation despite the above-mentioned, more critical and strict approach in other fields of politics.

Anyway, from a geographical point of view, the design, construction and implementation of the Geumgangsan Special Tourist Zone in 1999 and the Special-Economic Zone in Gaesong, also called the Gaesong Industrial Complex (GIC), in 2002, were still the most outstanding, tangible and surprising achievements in matters of crossborder cooperation. This statement is true despite the fact that each special economic enclave is separated from the rest of the DPRK by fences and military control points.

As for the Geumgangsan Tourist Area, activities were stopped when a South Korean tourist was shot to death by North Korean military in March 2008 (Reuters online 2008). Since North Korean officials refused further investigations demanded by South Korea and mutual allegations of provocation or espionage made the round, no more Geumgangsan trips were offered by tour operators.

Soon after, in 2009, the Gaesong Industrial Park became subject to further tension. First, a South Korean citizen was arrested and accused of anti-DPRK propaganda. Later that year all contracts and agreements of this SEZ were cancelled unilaterally by the North-Korean regime (Süddeutsche Zeitung online, 15 May 2009). Although further negotiations could prevent the initially announced changes from being applied, the
North Korean side had lost credibility. But trust and reliability are basic features of any successful undertaking (e.g. Lorenz 1992), not only in capitalist societies. This is certainly true for successful cross-border cooperation as well (Kortelainen \& Köppen 2009).

The rock bottom in North-South relations was finally achieved when a South-Korean battleship (the Cheonan) was allegedly attacked and sunk in South Korean maritime territory by a North Korean submarine, killing 46 sailors (Reuters online, 22 May 2010).

In consequence, the Lee administration officially froze all remaining (trade) activities with the DPRK and also called the UN, whilst in North Korea troops were put on red alert, announcing readiness to answer any further accusations and actions by the South with military operations (Spiegel online, 25 May 2010). The Gaesong Industrial Complex was also subject to announcements of retribution and some South Korean citizens were expulsed, but astoundingly, production still seems to be going on as a matter of fact (Kim 2010).

At this point all steps towards a better Korean dialogue and common project cooperation were stopped and taken back (see also the North Korean statement at Reuters online, http://www. reuters.com/article/idUSTRE64O3YU20100525). Currently the tension between the DPRK and the Republic of Korea seems to be worse than ever since the ending of the Korean War.

Surprisingly, in September 2010 the Workers' Party of Korea held a conference concerning also questions of leadership in the North. "The Political Bureau of the WPK Central Committee decides to convene early in September, Juche 99 (2010) a conference of the WPK for electing its highest leading body reflecting the new requirements of the WPK and the developing revolution in which decisive changes are taking place in the efforts to accomplish the revolutionary cause of Juche, the cause of building a prosperous and powerful socialist nation." (http://www.kcna. co.jp/index-e.htm). Indeed, during this event a son of Kim Il Sung, Kim Jong Un, and the dictator's sister were promoted to the rank of a general, which also means that Jong Un has to be regarded as the "official" successor of his father as the nation's leader. Such a change also bears the 
slight chance for revitalising the Korean dialogue and maybe a revival of the SEZs, but currently there seem to be no signs of a significant change in this matter in North Korean politics (see also http://www.zeit.de/politik/ausland/2010-09/ Parteitag-Nordkorea-China).

\section{Special Economic Zones in communist North Korea?}

The establishment or even the concept of special economic zones in the DPRK, considered an extreme Stalinist-style socialist dictatorship, is surprising. Nonetheless, North Korea already had relevant concepts and experiences even before Sunshine Policy led to the Geumgangsan and Gaesong projects (Fig. 1).

The process started in the 1980s when the DPRK introduced a joint venture law to attract Western capital. "In the early 1990s, when the breakdown of the socialist bloc led to [...] economic difficulties, attempts to attract foreign investors were increased, however, again with not much success. In December 1991 at last Korea established a SEZ in the Rajin-Sombong area, about the region adjacent to Russia and China. [...] Tax incentives, a guarantee for profit repatriation and the custom-free import and export of raw materials, intermediate products as well as products related to the industrial production of the SEZ were among the special features of the SEZ" (Seliger 2006: 98). Due to a lack of appropriate infrastructure, its peripheral position as well as a lack of transparency and economic freedom, the project more or less failed (Dege 1995; Seliger 2006).

Similar to Chinese SEZs - which certainly have served as an inspiration - the main goals of the North Korean projects are the attraction of foreign capital, accumulation of foreign reserves, technology transfer, and the learning of new management techniques. Spill-over effects leading to a re-animation of the North Korean economy in general are another important aspect. The open conflict between the ideology, political and economic goals is obvious, yet almost invincible.
In terms of returns on investment ${ }^{3}$, North Korean expectations were high. In the end they proved to be quite unrealistic (Seliger 2006). Potential investors were finally scared off by wages higher than in Chinese SEZs or Vietnamese factories whilst productivity and the real qualifications of North Korean workers remained unclear. Not to mention a certain lack of trust towards the North Korean authorities as partners, making any investment a very risky deal.

The early years of the Kim Dae-Jung administration marked a turning point. "[...] Sunshine Policy towards the North was characterized by offers for talks, cooperation and economic aid. In the preparatory stage for the 2000 summit [...], North Korea began cooperating with the Hyundai conglomerate (chaebol). The showcase of this cooperation was the opening of the Geumgang Mountains and the shipping line to these mountains dear to Koreans on both sides of the border. This opening was purchased with a guaranteed monthly payment of millions of US dollars. In other fields, Hyundai bought exclusive economic rights - for up to US\$ 500 million. In 2000, Hyundai received a 30-year exclusive (monopoly) contract for the railway linkage between North and South, the telecommunication sector and energy, the enlargement of Tongcheon airport, the dam building project at the Imjim river, the further expansion of the Geumgang Mountains project, as well as the establishment of the special industrial zone on Gaesong in 2002. The establishment of special industrial complexes with South Korean chaebol was seen as a fast lane to modernization of the collapsed economy" (Seliger 2006: 99).

The year 2002 is crucial to the DPRK's policy of SEZs: the Geumgangsan Special Tourist Zone was established formally and the Gaesong Industrial Complex was agreed upon.

In the same year, North Korea announced the opening of a Special Economic Zone at the Chinese border, in Sinuiji (Kim 2003, Lee 2003). The Sinuiji project was influenced by the Hong-Kong model and should have a special legal status for

3 One should not forget that all investment in infrastructure, new housing and manufacturing plants is made by foreign partners. The DPRK provides the land, cheap labour, and has probably some increased costs on military supervision. 


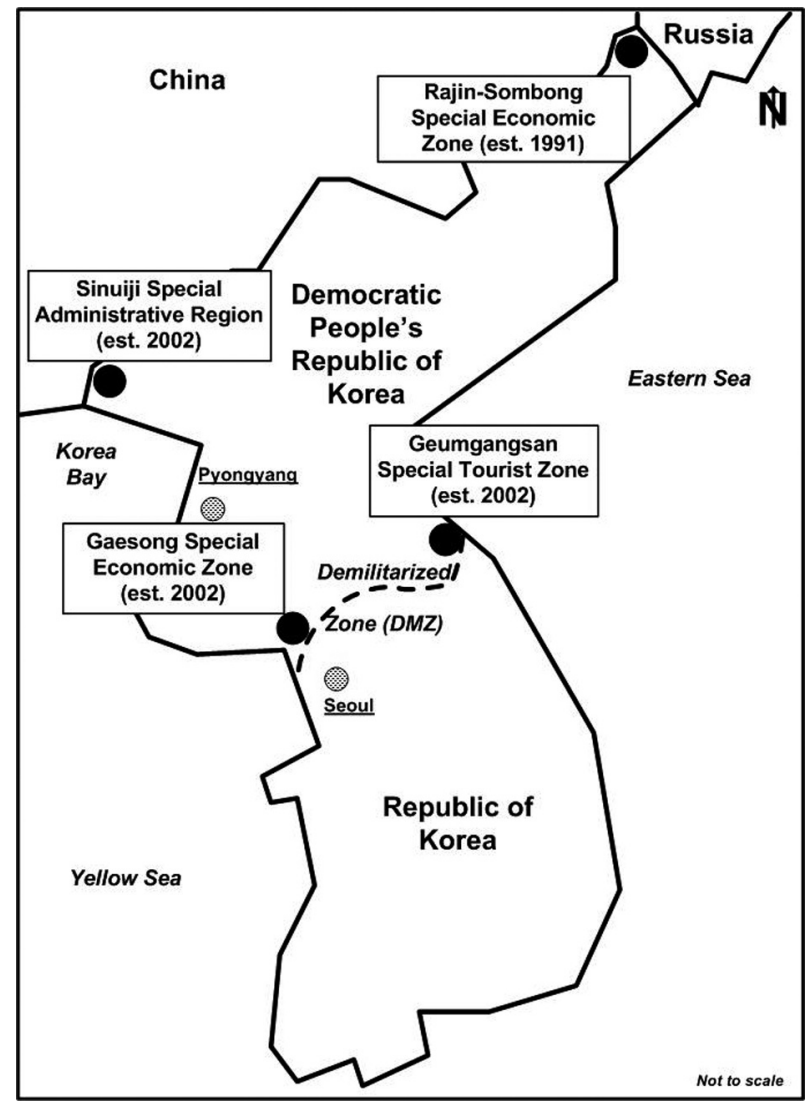

Fig. 1. The Korean Peninsula, DMZ and North Korean Special Economic Zones.

a period of fifty years. A special administrative status with own legislation was to allow private property, a separate monetary and customs system as well as an unrestricted movement of capital and further capitalist features. Furthermore, a part of the idea was the resettlement of tens of thousands of people in order to guarantee a loyal and "useful" population within this exclusive capitalist enclave (there are reports that at least the first campaign of resettlement has already started). The most particular characteristic of Sinuiji was the above-mentioned idea to establish not only a SEZ, but a hermetically closed Special Administrative Zone with a completely different economic and political system than in the rest of the DPRK. Despite this radical approach, the Sinuiji Special Administrative Region project was not recognised internationally.

Chinese-Dutch entrepreneur Yang Bin (who is said to be one of the richest people in China according to the Forbes rating) was foreseen to be the first governor of the Sinuiji Special Administrative Region. Soon after this became public he was arrested by the Chinese authorities. He was accused and found guilty of tax fraud amongst other offences. As there was already an existing special economic zone on the Chinese side of the border, in the nearby city of Dandong, Yang Bin's imprisonment is sometimes interpreted as a revenge for opening an "unfair" competition by the DPRK. Quite obviously Chinese decision-makers had not been informed about plans concerning the Sinuiji Special Administrative Region. All in all, this ambitious project could not be implemented. At least no tangible results are reported, although this SEZ does exist somehow.

In contrast, the implementation of the Geumgangsan Special Tourist Zone and the Gaesong Industrial Complex was more successful. Here, the legal status and economic approach were less radical than those planned for the Sinuiji Special Administrative Region.

\subsection{Geumgangsan Special Tourist Zone}

As already mentioned, there is a strong relation between Sunshine Policy, the implementation of the special zones, and the South Korean tycoon, Chung Ju-Yung, founder of the Hyundai chaebol.

When reports of starvation and the economic disaster in North Korea became internationally known in the 1990s, Chung - who was born in the Gaesong region in North Korea - took the initiative by sending 500 cows to the DPRK in 1998 (the cattle was send through Panmunjom; they called the later "unification cows"). He met Kim Jong-Il four times and finally got an agreement for opening the Geumgang (Diamond Mountains) range, directly located at the $\mathrm{DMZ}$, for tourist trips.

Further steps were taken by the developing company Hyundai Asan, a spin-off of the Hyundai chaebol, which also played a major role in the Gaesong Industrial Park project.

Since cross-border infrastructure and even legal regulations for South-North tourism were unclear, Hyundai Asan started trips by boat already in 1998, entering international waters before heading for Goseong harbour in the DPRK, as travelling a direct route between the two countries was in principle illegal (even later, regulations stayed very strict). Meanwhile new tourist 


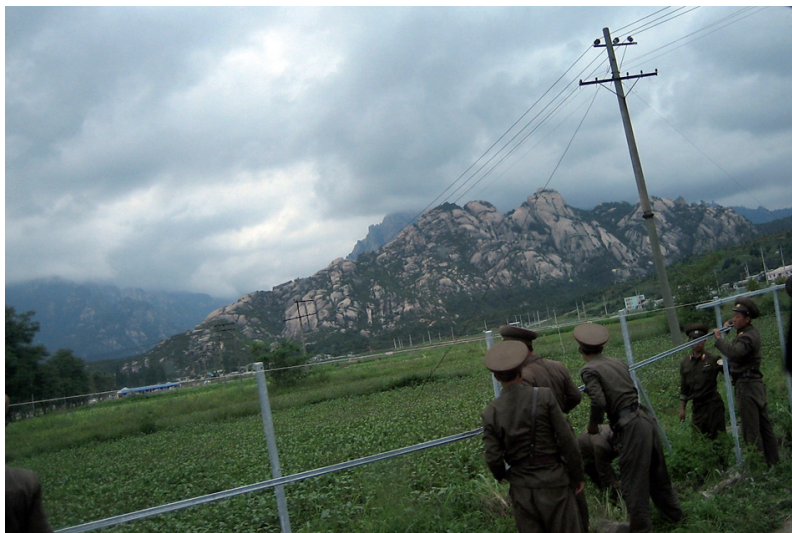

Photo 1 . North Korean military maintaining the inner fences of the Geumgangsan Special Tourist Zone (2006).

and traffic infrastructure was planned and built. As the Geumgangsan - Diamond Mountains - are not only a place of Korean mythology, but also one of the best known mountain ranges of North Korea, facilities for mass tourism already existed, but needed renovation and did not always meet the desired standard as well as expected capacities by the optimistic Hyundai Asan developing company.

Just before offering direct bus trips on an exclusively agreed land route from the South to the North, the designated tourist zone was separated from the rest of the North Korean Goseong County in 2002. Fences and omnipresent military guards are set up along all roads travelled by tourist buses (Photo 1).

In order to somehow save the regime's face, considering the mendacious character of such a capitalist project to be undertaken by the North Korean authorities, officially Hyundai Asan was hired to develop and manage the tourist zone on behalf of the DPRK. On the other hand, the company has to pay a monthly fee of about US $\$ 12$ million to North Korea (Seliger 2006) in order to be permitted to run its business.

Although one million visitors were counted by June 2005, the project did not meet the economic expectations. Hyundai Asan faced major problems. Reportedly the company faced bankruptcy due to its enormous investment and low returns. Despite massive financial aid given by the South Korean government, even the monthly fee could not be paid any more at a certain point (Seliger 2006).
As Geumgangsan is a highly important symbol for South Korean policy, finally a state-owned Korean National Tourist Organisation (KNTO) joined in to save the project. Thus, from that moment, all expenditures were secured and backed up by South Korean taxpayers through state subsidies for Hyundai Asan. Eventually even a further expansion of the site (including a golf course, ski-facilities, etc.) was planned before the area was closed down in 2008 for political reasons.

Within the zone, two major branches of facilities (mainly hotels and restaurants) had been established: Southern, "Hyundai" ones and North Korean enterprises. To visit the latter, hard currency had to be changed into coupons. In order to ensure a Southern standard in the quality of Hyundai-run facilities, they were supplied with their own electricity, food and goods. Therefore a power plant, greenhouses and even a mineralwater factory had been set up in situ. Further goods were regularly brought in from the South (e.g. building materials).

As a consequence, all the North Korean facilities (restaurants, hotels) and - certainly - the fenced off, nearby villages and towns suffered from a lack of infrastructure and goods. The most obvious signs of this situation were frequent interruptions of electric power supply in the North Korean facilities and the city of Goseong, which was not accessible but in sight (or sometimes not, during nighttimes). No such problems faced directly the Hyundai buildings. The difference between the Hyundai-maintained infrastructure and the North Korean standard was clearly visible and harsh.

Besides, a three-class human-resources system was used to run and build the area. North Korean citizens could be found as personnel in all the "own-run" facilities. Also surveillance and "security" by a permanent control of tourist excursions was visibly handled by the DPRK authorities. Any other citizens not directly involved in the tourist business were not allowed to enter the fenced tourist zone. Contact with foreigners was absolutely not intended, probably even forbidden. Ethnic Koreans from China were employed by Hyundai Asan for most labour-intensive jobs of low responsibility, from service to construction. They were neither allowed to enter South Korea nor to exit the Special Tourist zone, but 
functioned as classical seasonal workers. Key positions as well as high-responsibility tourist services were held and provided by South Koreans.

As a consequence, the Geumgangsan Special Tourist Zone showed a unique and bizarre mixture of perfectly organised mass tourism in an area completely controlled by an omnipresent, conspicuous North Korean military apparatus and secret service/ political police.

Apart from that, there was no indication that the Special Tourist Zone did initiate tangible reforms in the DPRK. However, there were surprising attempts at grass-roots cooperation by local politicians from the South Korean part of Goseong Gun (county). The idea was to get the North Korean Goseong county - where the Diamond Mountains are located - involved into agricultural projects. This initiative seemed to be somehow tolerated by the authorities, at least as long as it stayed at the level of discussion.

The gradually worsening political relations did not omit Geumgangsan. Whilst Hyundai Asan was trying to offer more trips and built new attractions, the North Korean missile launching and nuclear test in 2006 damaged not only the inter-Korean dialogue. About $40 \%$ of tourists who had already booked finally cancelled their planned trip in that year (Kim 2007).

As has already been mentioned, all activities came to a sudden, indefinite end in 2008 when a South Korean tourist was shot by North Korean border guards. Hyundai Asan suspended its trips.

It is quite interesting that - after more than a year - this boycott does worry the North Korean authorities in the end. Geumgangsan trips were seemingly of some significance as a source of (legal) hard currency.

In May 2010 the state news agency KCNA announced "extraordinary measures" unless tourist trips are continued again. In a first step, five South Korean properties have been seized, as a measure of compensation for the damage the North suffered due to the suspension of the tours since 2008. "The five facilities to be seized include a fire station, a duty-free shop and a Red-Crossbuilt centre to host family reunions. The official said the properties would be returned to state possession or "handed over to new businessmen according to legal procedures". All remaining as- sets will also be frozen and South Korean personnel expelled from the resort, said KCNA." (BBC news online, 25 May 2010; http://news.bbc. co.uk/2/hi/asia-pacific/8639065.stm).

Since mid-2010 a China based startup, Young Pioneer Tours, has obviously tried to offer Geumgangsan trips through the Northern side with permission of the North Korean authorities (http://www.youngpioneertours.com/ shownews.php?ID=18, last access 5 July 2010).

\subsection{Gaesong Industrial Zone}

During the summit of June 15, 2000, not only tourist business in Geumgangsan was agreed on, but also the establishment of a Special Economic Zone near Gaesong, a border town in proximity to the $\mathrm{DMZ}$ and just about $80 \mathrm{~km}$ north of the South Korean capital Seoul. The basic idea was to plant a germ for future positive North-South economic relations and establishing a potential regional hub for low-cost manufacturing for South Korean and international enterprises. As for the DPRK, this Industrial Park had been regarded as a fast lane to a modernisation and revitalisation of the collapsed North Korean economy (Yoon 1999). This mixture of political motives, such as patriotism and the desire to reduce the costs of eventual unification through aiding the North now, together with economic motives seems quite unique.

The leading South Korean partner was - again - Hyundai Asan with a monopoly contract. Very early, the (South) Korean Land Corporation (KLC or KOLAND), a governmental agency acquiring, managing, developing and supplying land, entered the project. KOLAND gave financial guarantees to the DPRK in order to support Hyundai Asan in case of (financial) problems. This was due to the experience of Geumgangsan, were economic problems endangered the whole project. And as was the case in Geumgangsan, the new activity of Hyundai Asan was backed up by South Korean tax payers. "The South Korean government seems to be willing to cover up to fifty percent of the losses of ventures in Gaesong through the so-called Inter-Korean Cooperation Fund, a fund operated by the South Korean Export-Import bank of Korea, which amounted to 
4.26 trillion won (US\$ 3.6 billion) at the end of 2003. So, the risk of investing in Gaesong [is] considerably reduced" (Seliger 2006).

Officially, the promotion of Inter-Korean economic cooperation in the framework of the Gaesong Industrial Complex development should contribute to easing military tension, bringing stability and peace to the Korean Peninsula, as well as resolving the North Korean nuclear issue (White book; Korean Ministry of Unification). However, most criticism points out that the project was merely a way for large South Korean companies to employ extremely cheap labour, and a reliable source of hard currency for the bankrupt North Korean regime.

Location was an important issue as the project area is connected to the Republic of Korea via a land-based transportation route (street and rail). Due to its proximity to the border and the capital region of Seoul, even energy can be produced in the South and transmitted to Gaesong avoiding dependence on poor North Korean facilities.

The Industrial Complex was formed in 2002 and became operational in the end of 2004. In 2005 , the project reached a stage when production of goods in the first plants had started. Most official bulletins see Gaesong as a "win-win" project, as it is designed to combine the capital and technology of South Korea with the land and workforce from the North.

Initially, within the Special Economic Zone freedom of persons and freedom to use communication systems (post, fax, the Internet) were guaranteed. There was no import and export tax, and land could be leased for up to 50 years.

About 6,000 North Koreans worked under South Korean direction, producing pots, footwear, textiles and other goods primarily for the Southern market (Salmon 2006). The number of South Korean specialists was about 600 .

But the final plans for Gaesong went much further: a complete new city for a population of more than 300,000 was to be built (Ryu 2007). The old Gaesong city itself was envisaged as a cultural tourism zone, attracting the history-hungry citizens of Seoul with the world's largest extant collection of Korean traditional architecture (Salmon 2006). The benchmark already for 2010 was to host 300 export-oriented South Korean SMEs employing 100,000 North Koreans (Erling
2007). Even more ambitious were further plans. In 2020 a total of 2,000 enterprises and 200,000 workers was foreseen. Other reports mentioned the idea of expanding the site to 6,610 hectares by 2012 and developing it into a regional manufacturing hub, marrying Southern capital and expertise with the skills of up to 700,000 Northern labourers (Ryu 2007).

Reality proved to be less exciting. Major obstacles occurred already during the very short period of work in Gaesong. First, the labour costs of US\$ 80-100/month initially assumed by North Korea proved rather too high. Only after reducing them to US\$ 50/month did Gaesong become competitive with such places as Vietnam (where US\$ 50 to 60 are paid) or China (where US\$ 50 to 100 are common wages). Secondly, the workers themselves did not really benefit, since wages were not paid in US\$ or Euro (although this was agreed upon). Thirdly, U.S. economic sanctions against the North caused another problem as imports of key technologies and sophisticated goods are prohibited. Furthermore, the U.S. accused the DPRK of having spent the wages for maintaining its programme for weapons of mass destruction, an allegation rejected by the South Korean Ministry of Reunification by pointing out that about $74 \%$ of the pay-offs had been actually used for purchasing "necessities". This means the money was used to buy foodstuff which was distributed in Gaesong. Meanwhile also South Korean managers started to complain about certain conditions. They demanded a more direct and autonomous management with less control and limited possibilities of intervention by the North Korean authorities. Also North Korean workers were obviously not always sufficiently educated and trained (although an opposite statement can be found in the South Korean media as well) (Ryu 2007).

Whilst the Gaesong Industrial Complex is a well-promoted figurehead of South Korea's policy for peace, understanding and economic development, the DPRK obviously did not advertise the project too much. On entering the Special Economic Zone from the North, there was no sign, no evidence that this place even exists (Erling 2007). Even the internationally noted propagandistic train that ran across the border in 2007 as a starting event for a regular cargo serv- 
ice from South Korea to Gaesong and back (Jung 2007) had been kept secret by the North Korean regime from its own population as far as possible. There were neither reports nor official statements about that event in the national or local media of the DPRK (Hanns-Seidel-Stiftung 2007).

At an individual level, a more and more relaxed atmosphere between North Korean employees and the few South Korean managers was reported. On the other hand, "The contrast between the complex, with its modern buildings, utility poles and street lighting - even a lawn and its surroundings is striking. Beyond the 8.6 $\mathrm{km}$ green perimeter fence, soldiers patrol. Against one section of fence is a drab village. The grey concrete of the shabby houses, set amid plots of brown dust, is cracked and crumbling. Many of their windows, lacking glass, are filled instead with sheet plastic. Officials of the complex say they have assisted local villagers with heating briquettes and rice, but there is otherwise neither trade nor contact across the fence, indicating that the experience of capitalism is strictly insulated. This assumption is buttressed by relations inside the complex: despite talk of inter-Korean fraternity, social contact between Northern and Southern workers is non-existent. "It is absolutely impossible to socialize; it is prohibited by the authorities," said Yoo Nam-yeol, a South Korean production manager at Taesang Hata, a firm producing cosmetics containers" (Salmon 2006).

When North Korea cancelled all contracts unilaterally in 2009 and announced plans to more than triple the salaries of its approximately 40,000 workers in Gaesong (from about US\$ 75 to 400), Hyundai Asan and KOLAND were finally able to agree on much less dramatic changes and kept operations going (see also news24.com, 11 June 2009).

All in all, the Gaesong Industrial Complex does not seem to be such a success as was claimed by most media, Hyundai Asan and government officials (Salmon 2006, Kim 2007). After the DPRK reneged on all contracts in 2009 and closed down as a reaction to the Cheonan affair in 2010, its future remains unclear. On the one hand, the SEZ is used to blackmailing the South Korean side. On the other, the end of the Gaesong Industrial Complex is nothing North Korea's regime could cope with easily.
What seems to be true for Geumgangsan quite obviously can be observed in Gaesong too: although the SEZ is somehow misused as "hostage" in the current confrontation, the DPRK fears a total break-off by the South. Maybe the experience of Geumgangsan with an unexpectedly consistent attitude by the tour operators made the regime cautious about really losing this source of income. There are reports that despite the officially announced expulsion of South Korean personnel in May 2010, operation continues almost as usual. "However, despite their rhetoric, the North Korean military authorities granted entrance to the Kaesong Complex for South Korean personnel this morning. Movement into and out of the Kaesong Complex is continuing normally, while fixed-line telephones connecting the Kaesong Industrial Complex and parent corporations in South Korea are operating without any problems, too. This appears to display North Korea's underlying desire to continue operating the Kaesong Industrial Complex even while warning that "all communications between South and North are severed" (Kim 2010, NK daily online).

\section{How to assess DPRK's unpredictable policy?}

North Korea's politics are somewhat incomprehensible and unpredictable to others. "Generous" gestures by the South can lead to dialogue and then be followed by sheer provocation such as missile tests or the breach of contractual obligations. Often, news from North Korea is not good news. North Korea keeps causing surprise. Kim Jong-Il is labelled a madman, his policy seems absurd. But the idea that Kim Jong-Il and his regime is an example of an insane (army-) posse is quite improbable. If this were the case, the country would have broken down a long time ago. Despite continued famine and economic disaster, the regime has been in power for decades and has even imposed some of its will on the international community. The DPRK is not a failing state, as is sometimes supposed. It might be a state with an incredibly brutal regime based on a self-made quasi-religious ideology perverting some traditions rooted in Confucianism (Maretzki 1991), but it is a working, still functioning state. 
The DPRK's role in world policy is marked by high caution, maximum self-sufficiency and a notoriously hostile attitude towards any "other". This is not so surprising, as the North Korean variation of communism, the Juche ideology, is based on the paradigm of total self-reliance and self-sufficiency. Under the rule of Kim JongIl, a pro army policy called Songun (army first) was added to Juche, giving absolute priority to military concerns and viewpoints. These two basic factors should be kept in mind when trying to understand North Korean politics; also in the context of cross-border interaction and reconciliation with the Republic of Korea.

However, in view of the principles of Juche and Songun and the fact that North Korea faces a more and more hopeless economic situation, things become more understandable. Piecing all - still few - known parameters on the DPRK's leader and his inner circle together, it is very likely that an increasingly desperate struggle for survival is a major, if not the only, concern of Kim Jong Il's regime. The Korean people and the international community are solely regarded in terms of use or potential danger to the North Korean elite. Any suspected destabilising tendency meets with an aggressive, pitiless response.

In international and inter-Korean affairs, brinkmanship seems to be the strategy of choice to safeguard a maximum of the regime's interests. Just shortly before things become too precarious, concessions are eventually made. But these concessions are taken back immediately if they might endanger the regime's supremacy or if they are just not necessary any more to keep DPRK society functioning.

Some examples: About 2002 the North Korean price and wage system was reformed and some kind of small private markets were established. Even the possession of cell phones was allowed to individuals (being a very popular measure). Foreign businessmen, namely from China, started to bring in more or less sophisticated trade goods. Along with them also came more unfiltered information from the outside world. DVD players and DVDs, even from South Korea, seemed to be owned by some people, at least in the urban centres. As a result, South Korean youth trends in clothing and hairstyle could be "detected" in the DPRK for some time (probably seen on imported
DVDs). Considered a potentially destabilising element to the regime, certain hairstyles were soon forbidden by the authorities ${ }^{4}$. Cell phones became illegal as well when it was realised (or maybe just verified what security forces had already known before) how important control of communication is in order to eliminate the danger of a forming opposition in the earliest stage possible. Despite the close surveillance of the North Korean people, there seems to be also growing discontent, namely in peripheral regions, as revealed by unofficial reports of famine revolts against regime representatives in some remote counties. As these incidents were obviously uncoordinated, singular riots (also due to a lack of means of communication), they could be put down by the police and army easily ${ }^{5}$. Today, basically a small private-market system still seems to exist. But even this kind of private economy with non-regulated prices was only tolerated temporarily as long as it was urgently needed to somehow provide badly needed consumer goods and food. Obviously, stricter regulations were enforced later again.

Thus, to ensure the regime's survival, concessions are made, sometimes on a temporary basis, even if they do not fit perfectly into the Korean style of communist ideology. However, the regime is far from significant reforms. A flexible shifting from repression to concession and back seems to be a central, characteristic feature of the regime's policy at the national as well as the international level.

The above conjecture as to Kim Jong-Il's policy could explain why many actions of the DPRK regime seem irrational and unpredictable to outsiders whilst being logical from the point of view of the North Korean elites.

From a North Korean perspective, a SEZ with a purely capitalist approach and even crossborder cooperation can be tolerated if this is an inevitable but feasible strategy to follow the primary goal of guaranteeing the survival of the North Korean statehood. Hostile acts, even to-

4 Information provided in interviews on the current situation in the DPRK by the Seoul-based office of the Hanns Seidel Foundation.

5 Statements on the North Korean policy and situation by Bernhard Seliger, representative of the Seoul-based German NGO Hanns Seidel Foundation dealing with the question of a divided Korea and the DPRK. 
wards "partners", could be both in this context: a consistent expression of the ideological beliefs, or a strategy to strengthen the regime's power and impose its will on other governments and the international community. More prosaically, it might be that North Korea's reputed incalculability in the Korean and international affairs is nothing more than a result of boundless selfishness and hubris of the regime.

\section{Illusion of cross-border cooperation between the two Koreas}

In spite of all problems, and even the current tension, it must be stated that at least there was a Korean dialogue with tangible results. From a South Korean viewpoint, even the border became permeable.

However, the Geumgangsan Special Tourist Zone and the Gaesong Industrial Complex were treated in a very specific way by the Northern regime before using them as a platform for choreographies of cross-border interaction in order to obtain the urgently needed hard currency.

Both zones had a contract-based, special economic and legal status. They were fenced off from the rest of the DPRK and frequented by specially selected (probably tested and loyal) workers. Whilst all development was due to investments from the South, the SEZs were easy to use for political blackmail by the North Korean authorities, given the total control and the arbitrary behaviour of the regime. It was not only once that the DPRK authorities used the SEZs as a leverage for pushing the South.

As to the South Korean idea of encouraging political reforms and changes through economic cooperation, it was clear from the beginning that such a tendency was absolutely avoided by the DPRK. That is why the SEZs were fenced off. Workers in the Gaesong Industrial Complex basically commute to the factories by bus on a daily basis, and information about Geumgangsan and Gaesong as well as further activities is suppressed in the official North Korean media or released if suitable for propaganda.

Hence, the so-called cross-border cooperation took place in a purpose-built buffer zone (Fig. 2).

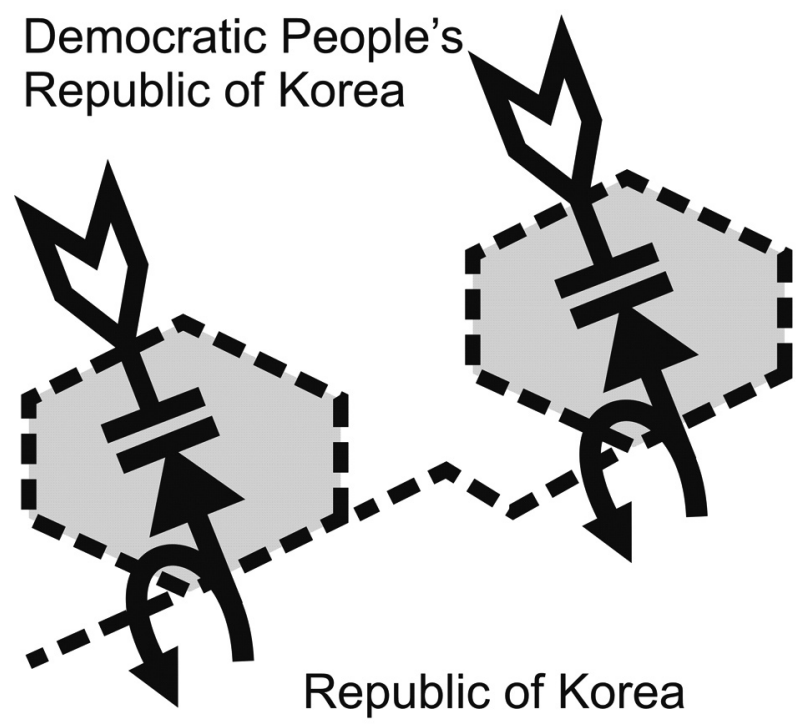

Fig. 2. North Korean Special Economic Zones as buffers preventing further integration through cross-border cooperation.

Not surprisingly, the extent of cross-border integration was very low.

The Special Zones are spatial entities of which each side had its own way of interpretation about what should be achieved. The range was not that broad anyway. Purely economic interest seemingly dominated the DPRK's and Hyundai Asan's motivation, whilst non-materialistic ideas of reconciliation and mutual understanding are the sphere of South Korean politics. Nevertheless, the South's attempt was perceived as quite altruistic to a certain extent, since there was always distinct readiness for large concessions in order to get into further projects with the DPRK and resolve any problem or just maintain the dialogue. Certainly, this policy was not totally spiritual, as peace and stability are the most important factors for a capitalist, export-oriented economy.

From a more theoretical point of view, the Special Economic /Special Tourist Zones can also be classified as a result of institutional practice and as symbols in a discourse. Putting emphasis on cross-border cooperation, it must be stated first that cooperation is the antithesis of competition. The motivation to cooperate is basically to reach mutually agreed common goals, which cannot be achieved so easily (or at all) by acting alone. However, cooperation is not necessarily joyful. It may be voluntarily chosen as an option, but also be a necessity as a matter of fact. Keeping in mind that there is no evidence that the North Korean 
government might be interested in any significant political or economic reform, but is in urgent need of humanitarian aid and hard currency, the observed cross-border cooperation with the Republic of Korea was more than likely forced. In contrast, the official South Korean policy was an informed choice seeking mutual understanding and reconciliation instead of continued confrontation.

Finally, so far the Korean SEZs could be mainly judged as a very specific example of institutional and economic cross-border cooperation without real spill-over potential for further integration.

\section{Résumé}

Summing up the short history of the North Korean SEZs, an amazing observation is that under certain circumstances it was possible to "open the gate" between North and South Korea a little bit at all. By creating the Geumgangsan Special Tourist Zone and the Gaesong Industrial Complex, the border was partially opened for almost one decade. It was even possible to think about new scenarios concerning the Korean future.

A fundamental knowledge of and experiences in cooperation with the DPRK has been gained by Hyundai Asan and KOLAND. Also, important spatial infrastructure, such as roads, railways and border checkpoints, has been built.

Nevertheless, these positive aspects cannot hide the central problems of inter-Korean relations. The major paradigms of North Korean Juche ideology, self-sufficiency, self-reliance and autarky, combined with Songun, "army first", policy withstand the integrative South Korean politics by nature (Kim 2002/Juche 91). Crossborder cooperation and integrative strategies for the border region cannot be a plausible feature of the actual North Korean state doctrine. The DPRK's concessions were obviously no result of reform and political change, but the consequence of sheer distress. After all, it should not be forgotten that the SEZs were one of the few sources of (legal) hard currency for the DPRK although their real relevance for the North Korean regime and economy remains unknown. But it seems more and more obvious that DPRK officials regret the suspension of Geumgangsan trips bitterly and do fear a similar situation for the Gaesong Industrial Complex. At least economic activities in this SEZ were carried on, even after their end had been officially announced by the North (Kim 2010).

That Gaesong Industrial Complex continues operations although all relations were officially announced to be stopped might serve as an indicator of how important this Special Economic Zone is for North Korea. If operations were really stopped, an estimated 40,000 North Korean workers would be unemployed and have to be transferred to other, "regular" workplaces (all over the country). The scenario feared by Northern officials is probably this: no more hard currency and the risk that some former employees might share their knowledge about the Gaesong Industrial Complex, the slightly better life there, and South Korea, with ordinary people in Kim's realm of the desperate and the obscure.

Continued provocative acts of the DPRK towards the Republic of Korea as well as the international community have finally led to a new period of alienation and proved how fragile and vulnerable cross-border relations between the Korean states are. Maybe even an extremely low level of integration in cross-border cooperation would not be that problematic if it guaranteed - at least - some stability to the Korean peninsula. But at this point, the North Korean strategy of brinkmanship almost led to a total standstill in cooperation. Obviously the major challenge of the Northern regime is neither cross-border cooperation nor reconciliation, but a permanent struggle to feed its people facing an underdeveloped economy, while a maximum of disposable resources are channelled into the military and the nuclear programme. There is no evidence that a "soft landing" is even thinkable for the North Korean economy, whether now or in the near future.

It is impossible to predict when, or if, a revival of the Korean dialogue might take place. At least there has been talk about a new family meeting in Geumgangsan very recently. Also the current changes in the DPRK's leading body might be a slight chance, as a lasting improvement in the permanently problematic relationship between the North and the South is basically dependent on significant changes in the North Korean paradigms. 


\section{References}

Dege E., 1995. Ein neues Hongkong für Ostasien? Das Tumen River Area Development Programme. Geographie Heute, 38-41.

ERLING J., 2007. Nordkoreas Traum vom Kapitalismus. Die Welt-online, 16 June 2007. www.welt.de/wirtschaft/artcile951152/Nordkoreas_Traum_vom_Kapitalismus.html

HANNS-SEIDEL-STIFTUNG, Seoul office , 2007. Halbjahresbericht 1. Halbjahr 2007. Seoul. (working paper).

JUNG SING-KI, 2007. Koreas finalize details for train test runs. Korea Times, 14 May 2007.

Kim Chae-Han (ed.), 2001. The Korean DMZ. Seoul.

KIм CHOL-U, 2002/Juche 91. Songung politics of Kim Jong Il. Pyongjang.

KIM KWANG-IN, 2003. Lots of publicity on Sinuiji SAR. Digital Chosun, 10 October 2002. http://english.chosun.com/ w21data/html/news/202010/200210100015.html.

KIm So YeOL, 2010. North Korea responds to firm South Korean stance.DailyNKonline,26May2010.http:/ / www.dailynk. com/english $/$ read.php? cataId $=$ nk00100\&num $=6417$ (last access 8 July 2010).

KIM Yong-Hun, 2007. Truth revealed behind companies in Kaesung. The Daily NK, 17 May 2007.

KIRK D., 2003. South Korean leader says move was meant to aid "sunshine" policy: Payment to North puts Seoul on defense. International Herald Tribune, 31 March 2003.

Kortelainen J. \& Köppen B., 2009. "Trust" as a basic factor for effective cross-border co-operation: The examples of the German-Czech and Finnish-Russian border areas. In: Fritsch M., Jurczek P., Köppen B., Kortelainen J. \& Vartiainen P. (eds), Cross-border structures and co-operation on the Finnish-Russian and German-Czech borders: A comparative perspective. Reports of the Karelian Institute 2/2009: $17-29$.

LoREnZ E.H., 1992. Trust, community and cooperation: Toward a theory of industrial districts. In: Storper M. \& Scott A.J. (eds), Pathways to industrialization and regional development. London, Routledge: 195- 204.

LeEKYo-KwAN, 2003. Sinuiji Special Administration Region development underway. Digital Chosun. http:/ / english.chosun.com/w21data/html/news/200301/200301080026. html.

MaretzKi H., 1991. Kimismus in Nordkorea. Eine Analyse des letzten DDR-Botschafters in Pjöngjang. Böblingen.

Martinez O.J., 1994. Border people. Tucson.
Nachfolger für Kim Jong Il? Die Zeit online, 26 June 2010, http://www.zeit.de/politik/ausland/2010-06/nordkorea-kim-jong-il.

N Korea demands millions. news24.com, 11 June 2009, ttp:/ / www.news24.com/World/News/N-Korea-demandsmillions-20090611 (last access 6 July 2010).

Nordkorea kündigt Verträge mit Seoul. Sueddeutsche online, 15 May 2009, http://www.sueddeutsche.de/politik/2.220/industriezone-kaesong-nordkorea-kuendigtvertraege-mit-seoul-1.465399 (last access 5 July 2010).

North Korea "to seize property at Kumgang resort". BBC news online, 23 May 2010, http://news.bbc.co.uk/2/hi/ asia-pacific/8639065.stm (last access 5 July 2010).

North Korea torpedoed South's navy ship. Reuters online, 22 April 2010, http://www.reuters.com/article/idUSTRE63L08W20100422 (last access 15 June 2010).

OH YeAn-Cheon, Park Sung-Jo \& Bernhard S., 2005. The unification research and strategy in Korea and Germany. Seoul.

OMAHE K., 1995. The end of the nation-state - The rise of regional economies. London.

PAAsI A., 2003. Boundaries in a globalizing world. In: Anderson K., Domosh M., Pile S. \& Thrift N. (eds), Handbook of cultural geography. London, Sage: 462-472.

RYu J.,2007. Gaesong site expedites S-N economic integration. Korea Times, 30 April 2007, http:/ / www.koreatimes. co.kr/www/news/special/2009/04/180_2069.html (last access 9 July 2010).

Salmon A., 2006. Kaesong zone a troubled Korean jewel. Asia Times Online, 6 April 2006) http://www.atimes.com/ atimes/Korea/HD06Dg01.html (last access, 9 July 2010).

Seliger B., 2006. At the interface of the local, the national and the global - environmental issues in the border regions of divided and unified Germany and perspectives for Korea. Seoul.

Streit über versenktes Kriegsschiff. Nordkorea versetzt Truppen in Kampfbereitschaft. Spiegel online, 25 June 2010 (last access 5 July 2010).

South Korean tourist shot dead by North soldier. Reuters online, 11 July 2008, http://www.reuters.com/article/ idUSSEO14908720080711 (last access 1 May 2010).

Text from North Korea statement. Reuters online, 25 May 2010, http://www.reuters.com/article/idUSTRE64O3YU20100525 (last access 5 June 2010).

Yoon DeAoK-RYong,1999. Economic effects on the development of industrial complexes in North Korea and strategies for successful development. The Economic of Korean Reunification, 4 (2): 139-153. 